\title{
GENUINE REDUNDANCY AND RETRENCHMENT COMPENSATION: AN ANALYSIS OF MALAYSIAN LAW
}

\author{
Ashgar Ali Ali Mohamed ${ }^{1 \star}$, Mohammad Naqib Ishan Jan $^{2}$, Muhamad Hassan Ahmad ${ }^{3}$ \\ Arun Kasi ${ }^{4}$ \\ ${ }^{1}$ Prof. Dr. Ahmad Ibrahim Kullyyah of Laws, International Islamic University MALAYSIA Email: \\ ashgar@iium.edu.my \\ ${ }^{2}$ Prof. Dr.Ahmad Ibrahim Kullyyah of Laws, International Islamic University MALAYSIA Email: \\ naqib@iium.edu.my \\ ${ }^{3}$ Assistant Prof. Dr. Ahmad Ibrahim Kullyyah of Laws, International Islamic University MALAYSIA \\ Email: mdhassan@iium.edu.my \\ ${ }^{4}$ Advocate and Solicitor, Arbitrator, Adjudicator, MALAYSIA Email: arunkasi@arunkasico.com \\ ${ }^{*}$ Corresponding author
}

\begin{abstract}
Retrenchment is a process to discharge the surplus labour arising due to various factors which renders the services of the redundant worker no longer needed by the employer. This might happen firstly, when the business itself ceases to operate or the business no longer exists, secondly, when the place where the employee was contracted to work disappears, thirdly, the job itself disappears and fourthly, when less employees are needed to do the same job while the job still exists. All these are brought about because of change in business as times are not always booming in the business world. In a genuine redundancy situation, it is pertinent for the employer to pay retrenchment benefits or compensation to the affected workers in order that they are able to cope with immediate aftermath of retrenchment. The retrenchment payment is a minimum sum paid to the employee based on the length of service for loss of the job.

Having said the above, this paper seeks to discuss genuine redundancy and the retrenchment compensation with reference to the law and practice in Malaysia. Here, unlike some developed countries such as the United Kingdom, not all workers will be eligible for the compensation in the event their services are no longer required by the organisation due to genuine redundancy in the organisation. Hence, this paper not only discusses what it means by 'genuine redundancy' and 'retrenchment compensation' from the Malaysian perspective but also proposes reform of the existing law to accord retrenchment compensation to all workers affected by the retrenchment.
\end{abstract}

Keywords: Redundancy, Retrenchment, Compensation

\section{INTRODUCTION}

Job stability in a country or state is generally dependent on the condition of economy in that country or state. Many countries around the world including Malaysia have experienced several economic recessions and downturns over the past years. The resulting effect was a slowdown of the economy, poor business conditions resulting in a slump in business that led many companies, including some of the biggest 
corporations, into difficulties because of the a significant drop in profit. They suffered big losses, some even having to restructure or reorganise their businesses in the form of take-overs and mergers. The worst of its effect would be closure of business. The hard-hit sectors were mostly manufacturing, commerce, transport, communication and finance.

This caused the rise in unemployment rate owing to retrenchment in many sectors of the business. It was reported that, in Malaysian, over 50,000 workers from the manufacturing, construction and the service sectors are expected to lose their jobs in 2018 due to the condition of economy. The figure is alarming and should not be brushed aside as insignificant on grounds that retrenchment is a common recurrent across the globe due to uncertainty of the world economy. This is particularly so when the said number is compared with the size of workforce in the country.

Undeniably, losing one's job due to retrenchment can be a distressing experience that has financial repercussion and psychological effects on the affected worker. The affected worker would be deprived of his major source of income and also tend to lose accumulated benefits such as seniority and retirement benefits and so on. The effect would be even more devastating during economic recession when unemployment would be common. A retrenched worker would face difficulty in finding another job with similar status. Often, the labour market would be flooded with other job seekers possessing very similar job skills and work experience. The effect would be more transparent when the worker had been in service for a long timeand when the worker had only specific skills, which may be of little use to potential employers in the market. In the current modern era with advanced technology moving from one job to another may not be an easy one and it may require some specialist skill in the worker

Coping with all these problems in turn can create an enormous amount of physical and mental stress, which may contribute to social and psychological disorders. This could lead to dissatisfaction with life, lack of selfesteem, lack of personal control and general psychological depression, which will increase with continued unemployment. Workers who are unable to use their skills in their new employment, or are not of intrinsic interest to the employers or are not given rewards that commensurate with their efforts and skills, are likely to go through psychological disturbance in the new employment.

Resulting from the loss of job, an affected worker would have to rationalise expenditure such as reduction in immediate consumption expenditures, cancelling insurance policies, using up savings and selling assets, etc., to afford the necessities of life during the interim period of unemployment and accompanying reduced income. Even if an alternative employment is secured, the workers and their families may have to accept relatively lower standards of living if the only employment that can be secured involves lower wages with reduced fringe benefits.

As from the above, job-loss justified by economic needs can create an enormous amount of physical and mental stress, which may contribute to social and psychological disorders. Where retrenchment is inevitable due to genuine commercial reasons, the employer must try to minimise the traumatic impact of the retrenchment on the workers and this includes preparing the affected workers to face the retrenchment and assisting them to find suitable alternative employment and so forth.

In this respect, the retrenchment benefits are paid to the affected workers with a view to helping them cope with the job-loss besides rewarding them for their loyalty and service to the company. It also provides the retrenched worker with means to sustain himself and his dependents until he finds another suitable employment. The newly enacted Employment Insurance System Act provides the retrenched workers with temporary financial assistances apart from assistance in the re-employment. Having said the above, this paper will discuss the genuine grounds of redundancy and the payment of compensation with reference to the laws in Malaysia.

\section{RETRENCHMENT MUST BE ON GENUINE COMMERCIAL REASONS}

It is trite law that any intended termination of employment contract must flow from a justifiable ground and this includes redundancy. Such redundancy must be on the basis of genuine commercial reasons and the decision to terminate the worker must be done in good faith and carried out with fairness. This has been clearly outlined in the 1982 ILO Convention on Termination of Employment (Convention No.158) where it specifies that the employment of an employee may not be terminated unless there is a valid reason connected with the capacity or conduct of the worker or based on the operational requirements of the undertaking.

The decision as to strength of the workforce needed in an organisation and the need for labour to carry out the day-to-day management of the organisation is the employer's prerogative. It is the right and privilege of every employer to reorganise his business in any manner he thinks suitable for the purpose of economy or 
even convenience (East Asiatic Company (M) Bhd v Valen Noel Yap [1987] ILR 363). The employer is empowered to introduce automation, or abandonment of unprofitable activities, reorganisation or undertaking other cost saving measures (Harris Solid State (M) Sdn Bhd \& Ors v Bruno Gentil s/o Pereira \& 2 Ors [1996] 4 MLJ 747).

Where necessary for efficiency of the undertaking, the employer is empowered to discharge its surplus. It is the right of an employer to reorganise his business in the way he likes for the purpose of economy or convenience provided he acts bona fide when it affects workers. The retrenchment should not be carried out for collateral purpose, for example, to victimise employees for their legitimate participation in union activities. The emphasis herein is on that the employer must ensure that any retrenchment exercise in its organisation is carried out in a fair and justifiable manner and is not done capriciously or with motives of victimisation or unfair labour practice.

\section{RETRENCHMENT COMPENSATION FOR LOSS OF EMPLOYMENT}

Furthermore, when a redundancy situation has caused a worker to be retrenched, the affected worker must be paid compensation for loss of employment based on the length of his service with the employer. The aim of the compensation is to help the retrenched employee cope with the immediate difficulties consequent upon job loss and to sustain himself until he finds another suitable employment. This is aside from rewarding him for his loyalty and service to the company. In Lloyd v Brassey [1969] 1 All ER 382, Lord Denning MR stated, inter alia, that redundancy compensation "is not unemployment pay. I repeat 'not'. Even if he gets another job straight away, he nevertheless is entitled to full redundancy payment. It is, in a real sense, compensation connected to long service".

Again, in Pengkalen Holdings Bhd $v$ James Lim Hee Meng [2000] 2 ILR 252, the Industrial Court, stated that the retrenchment compensation:

[S]erves as a cushion against the hardships faced by an employee who has to contend with the loss of his employment and the consequential loss of his immediate means to earn an income. In the context of good industrial relations practice, it serves to minimise resistance and opposition to genuine reorganisation measures undertaken by management. It acknowledges a workman's security of tenure and recognises the fact that though no fault of his, such security of tenure has to be given away to his employer's overriding interest of economy and efficiency.

Having said the above, it must be noted that not all employees would be entitled to retrenchment compensation in the event that there was a genuine redundancy in the organisation. Only the employee who is within the purview of the Employment Act 1955 is entitled to retrenchment benefits as provided by the Employment (Termination and Layoff Benefits) Regulations 1980. The amount of compensation that employees receive would depend on their last drawn monthly salary and the length of time they have served with the organisation.

Regulation 3 provides the general provisions for the entitlement of employees to termination or lay-off benefits payment. It provides that an employer shall be liable to pay termination or lay-off benefits payment to an employee who has been employed under a continuous contract of service for a period of not less than twelve months' ending with the relevant date if the contract of service of the employee is terminated or the employee is "laid-off" within the meaning of regulation 5.

If a worker qualifies under the Employment Act, he will be entitled to receive termination or lay-off benefits, as stated in regulation 6 and it shall not be less than -

(a) ten days' wages for every year of employment under a continuous contract of service with the employer if he has been employed by the employer for a period of less than two years; or

(b) fifteen days' wages for every year of employment under a continuous contract of service with the employer if he has been employed by that employer for two years or more but less than five years; or

(c) twenty days' wages for every year of employment under a continuous contract of service with the employer if he has been employed by that employer for five years or more, and pro-rata as respect an incomplete year, calculated to the nearest month.

Having said the above, it would be worthwhile noting that for workers who are outside the purview of the Employment Act, they may be entitled to retrenchment benefits if the collective agreement to which they are members stipulates for such payment. If the collective agreement contains a provision to that effect, it creates a "status", and if the strict terms of the conditions of the law creating a status are not followed it would be enforceable in the court and relief will be granted. 
IJASOS- International E-Journal of Advances in Social Sciences, Vol. IV, Issue 12, December 2018

For example, in Kesatuan Kebangsaan Pekerja-Pekerja Perusahaan Petroleum \& Kimia Semenanjung Malaysia v Hil Industries Berhad (Award No. 25 of 2010), the collective agreement provided, inter alia, that an employee, whose employment was terminated on grounds of redundancy, shall be entitled to retrenchment benefits as follows:-

(a) Half a month's (0.5) wages based on his last drawn basic salary for every year of employment under a continuous contract of service with the company if he has been employed by the company for a period of less than two years; (b) one (1.0) month's wages based on his last drawn basic salary for every year of employment under a continuous contract of service with the company if he has been employed by the company for two years or more but less than five years; or (c) one and a half (1.5) month's wages based on his last drawn basic salary for every year of employment under a continuous contract of service with the company if he has been employed by the company for more than five years.

The above condition operates as legally binding extra-contractual obligation imposed on the employer.

\section{EMPLOYEE INSURANCE SYSTEM ACT 2017}

The Employment Insurance System Act 2017 (the Act), which came into force on 1 January 2018, is a timely Act that aims to encourage the employees to seek re-employment apart from strengthening their employability in the labour market through placement programmes. It provides a new protection measure for the employees in Malaysia, providing certain benefits and a re-employment placement programme for insured person in the event of loss of employment which will promote active labour market policies. It applies to all industries having one or more employees who are Malaysian citizens or permanent residents in Malaysia. Thus, all employers in the private sector who have one or more employees are obligated to insure their employees.

The Act is applicable to all employees including part-time workers irrespective of the amount of wages. However, public servants, domestic workers, self-employed and few others as described in the First Schedule are excluded. The Act, which is administered by Social Security Organisation ("SOCSO"), intends to assist employees in situations where they have lost their employment. In addition to financial assistance, the Act has training programmes and job seeking assistance which are designed to help the insured persons return to work as soon as possible. It provides a number of benefits for the employees and these include job search allowance, early re-employment allowance, reduced income allowance, training allowance and training fee.

Job search allowance refers to a monthly payment for a period of three to six consecutive months to assist an insured person, who has lost employment, during the period of seeking employment. SOCSO will pay the insured person at the rate, on a monthly basis, as specified in the Third Schedule, namely: (a) $80 \%$ of the assumed monthly wages for the first month; (b) $50 \%$ of the assumed monthly wages for the second month; (c) $40 \%$ of the assumed monthly wages for the third and fourth month; and (d) $30 \%$ of the assumed monthly wages for the fifth and sixth month.

It should be noted that the higher rate at the early stage of unemployment is provided to reduce the burden of an insured person who has just been retrenched. The declining rate is set to encourage the insured person to actively seek re-employment. The payment for job search allowance shall be made to the insured person immediately after seven days following the date of the approval of a claim for such benefit ("waiting period").

Once the insured person is secured with an offer of employment during the 6 months' period, the insured should notify SOCSO within seven days after the date of acceptance of the offer. The job search allowance is payable to the employee even if he has attained the minimum retirement age if the loss of employment occured before he attained the minimum retirement age.

Early re-employment allowance refers to an incentive paid in a lump sum to an insured person for accepting an offer of employment from a new employer and commencing the employment within the waiting period or the period of receiving job search allowance at the rate as specified in the Third Schedule. The Act provides for early re-employment allowance to be paid to the insured person who receives a job offer and reports to duty within the waiting period or during the period of receiving a job search allowance. In such case, the insured person will be entitled to $25 \%$ of the total job search allowance or the total balance of the remaining unpaid job search allowance as described in the Third Schedule.

If the insured person accepts the offer within the waiting period, he may choose whether to accept the early re-employment allowance. If he chooses not to accept the allowance, then he shall be deemed to have never made the claim for such benefits. Also, it is important to note that no early-employment allowance shall be 
paid to the insured person after the six months period of receiving job search allowance expires.

Reduced income allowance refers to a lump sum payment to assist the insured person who has two or more employments and has lost one or more of them. If the insured person has two or more employments at the same time and has lost one or more, but not all of them, he will be entitled to a reduced income allowance for each loss of employment at the rate as specified in the Third Schedule. The reduced income allowance will be paid in a lump sum to the insured person. In this context, the insured person will not be entitled to a job search allowance, a training allowance or an early re-employment allowance.

However, if the insured person who has two or more employments loses all of the employments on the same date, he will then be entitled to one job search allowance for one loss of employment and a reduced income allowance for the other loss of employment, and he may select for which job he wants job search allowance. If an insured person has lost an employment he may apply to SOCSO to attend any training provided by a training provider approved by SOCSO during the period the insured person receives the job search allowance. This application must be done within the period of not more than 12 months after the insured person has received the job allowance, or within the period of six months after accepting an offer of employment and reporting to work. In this regard, the insured person will be entitled to a training allowance for not more than six months at the rate of $25 \%$ of the assumed monthly wages calculated on daily basis. The training allowance is capped at a minimum of RM10 and a maximum of RM20 per day which is paid monthly according to the number of training days attended by the insured person.

On another note, SOCSO shall bear and pay a training fee to the training provider, who provides the training to the insured person, which shall not exceed RM4,000. In the event that the insured person who is undergoing any training passes away, SOCSO should continue to pay the training fees to the training provider for the trainings attended by the insured person as agreed between SOCSO and the training provider. For the purpose of this section, 'training fees' means all costs relating to the training of an insured person including meals and materials for the training.

Re-employment placement programme refers to a programme managed by SOCSO for insured person for the purpose of re-employment. The Act requires the insured person to commence participation in the reemployment programme within the waiting period. The insured person is required to comply with directions given by SOCSO in respect of the programme, and shall be available to work, actively seek work, and undergo any training as necessary. If there is any offer of employment suitable to the insured person, SOCSO shall inform the insured person accordingly. In the event that the insured person refuses the offer without reasonable ground, the insured person will not be entitled to receive any benefits under the Act.

The Act requires every employer to register his industry with SOCSO. A failure to comply with this requirement renders the employer liable to a fine not exceeding RM10,000 or to an imprisonment for a term not exceeding 2 years or both. However, employers and employees who have registered with SOCSO in accordance with the Employees' Social Security Act 1969 shall be deemed to be registered under the Act.

\section{EMPLOYMENT INSURANCE PAYOUT ONLY TO RETRENCHED WORKERS}

The pay out under the Act is primarily intended to assist the workers who lost their jobs in situations when the employee has become a surplus to the requirement of the organisation due to various reasons. It must be reiterated that the employment insurance payout is only applicable to employees retrenched from employment through no fault of either party. It cannot be extended to an employee who was dismissed from employment on grounds of misconduct. Misconduct, the most common ground for dismissal, refers to unacceptable behaviour of the employee. It can be categorised into three sub-headings, namely misconduct related to duty, misconduct related to discipline and misconduct relating to morality. This includes but is not limited to insubordination, dishonesty, drug abuse, alcohol abuse, sexual harassment, negligence in duty, fighting while on the job, improper and unauthorised use of employer's property, destruction of employer's property, threatening, intimidating, interfering with or using abusive language towards others and any other acts directly relating to discipline. There is no requirement in law that the employer must prove that it had suffered actual loss before taking any disciplinary action against an errant employee.

Furthermore, misconduct can be classified into two categories of severity namely, gross or minor misconduct. Gross misconduct refers to serious offences which can take many forms, ranging from offences which jeopardise the functioning of the employer's business or the safety and well-being of the employees. This includes wrongs such as immorality at the workplace, insolence and insubordination, criminal conduct, or any other conduct inconsistent with the relationship of an employer and employee. Such wrong usually empowers the employer to dismiss the employee after giving him an adequate opportunity to refute the allegations framed against him. 
IJASOS- International E-Journal of Advances in Social Sciences, Vol. IV, Issue 12, December 2018

Meanwhile offences relating to work and work performance such as poor timekeeping, absenteeism, misuse of workplace facilities, bad personal appearance, negligence or sub-standard work, to name but a few, are usually considered as minor misconduct. Such wrongs would not warrant dismissal for a first offence, but may lead to a verbal or written warning and followed by a disciplinary hearing, if the misconduct is repeated or continues. Repeated minor misconduct such as tardiness, can, cumulatively, result in dismissal, subject to the proper procedures being followed. Hence, in the interest of discipline and fair labour practice, it is appropriate that the temporary financial assistances under the newly established employment insurance scheme should only be made available to an employee terminated from employment due to genuine commercial reasons and not dismissed from employment on grounds of misconduct.

\section{CONCLUSION}

Lose of one's job due to retrenchment can be a distressing experience that has financial repercussion and psychological effects on the affected worker. Where retrenchment is inevitable due to genuine commercial reasons, the employer must try to minimise the traumatic impact of the retrenchment on the affected workers and this includes preparing them to face the situation and to assist them in finding suitable alternative employment. Aside from the above, the retrenchment benefits are paid to the affected workers with a view to help them cope with the job loss besides rewarding them for their loyalty and service to the company. It also provides the retrenched worker with means to sustain himself and his dependents until he finds another suitable employment. Further, the newly enacted Employment Insurance System Act provides the retrenched workers with temporary financial assistances besides assisting in the re-employment placement. The employment insurance pay-out is only applicable to employees retrenched from employment through no fault of either party. It cannot be extended to an employee who was dismissed from employment on grounds of misconduct.

\section{REFERENCE LIST}

Ashgar Ali and Farheen Baig (2012). Retrenchment: The Law and Practice in Malaysia, Sweet \& Maxwell Asia, 48.

Maimunah, Aminuddin (2006). Malaysian Employment Law Practices, LexisNexis, Kelana Jaya, 302.

Ashgar Ali and Farheen Baig (2015). Retrenchment: Last In First Out (LIFO) Rule, Malaysian Current Law Journal, Ixxx.

Ashgar Ali (2015). The Viability of A National Retrenchment Scheme (NRS) in Malaysia. Industrial Law Reports (3), xvii. 